\title{
アメリカにおける航空規制緩和と 結節地域構造の変化
}

\section{藤 目 節 夫}

\begin{tabular}{|c|c|}
\hline I 既往の研究と本研究の目的 & 化とその要因分析 \\
\hline II 研究資料と研究方法 & N～航空旅客による結節地域構造 \\
\hline 航空会社規制緩和と航空旅客の変化 & 化 \\
\hline （1）航空会社規制緩和法 & （1） 規制緩和前の結節地域構造 \\
\hline (2) hub の種類と hub and spoke 方式 & （2）規制緩和後の結節地域構造 \\
\hline (3) 航空旅客の変化 & V 結 \\
\hline 孖る航空旅客の変 & \\
\hline
\end{tabular}

\section{I . 既往の研究と本研究の目的}

交通現象は経済学, 社会学, 都市工学, 土木 工学などのいろいろな分野で，それぞれ異なっ た研究目的を持って取り扱われているが，地理 学に和いてる，「交通は地域間の関係の尺度で あって，それゆ完地理学の本質的な部分であ る」との認識から，これまで数多くの研究がな されてきた。ところで航空交通は，他の交通と 比較して地理的スケールが大きくなるものの; 地域間の関係を表す尺度であることに違いはな く, 正しく地理学の研究対象である。それにも 関わらず，近年まで航空交通に関する研究は余 り多くなかった。清水はこの原因として「航空
現象は地表を離れた空中現象なので，地表現象 を対象とする地理学には初めから馴染ま邓もの であった」と指摘している。また，村山は航空 地理学を展望する中で，わが国に於て航空地理 学研究が余り見られない理由として，「航空交 通自体が可視的な交通景観を対象にするわが国 の伝統的な交通地理学の分析方法になじまなか った点にある゙うと指摘している。

初期の航空地理学の研究の多くは, 他の交通 地理学の研究と同様地誌的記載が中心であった が，この様な伝統的な地誌的地理学と一線を画 したのが Taaffe であった。彼はその一連の研 究に於て, 航空旅客に関する発生・集中交通量 や地域間航空旅客 O D 表などのデータに対して,

1) Ullman, E.D. and Mayer, H., 'Transportation geography', in James, P. and Jones, C. eds., American geography: inventory and prospect, 1956, pp.311-332.

2）清水馨八郎『空の交通之新空港』，大明堂，1978，12頁。

3）村山祐司「航空地理学の研究成果」, 人文地理 $38-4,1986,47-71$ 頁。

4) Taaffe, E. J, The air passenger hinterland of Chicago', Chicago: Univ. of Chicago, Dept. of Geography, Research Paper 24, 1952.

Taaffe, E. J., 'Air transportation and United IStates urban distribution', Geographical Review 46, 1956, pp. 219-38.

Taaffe, E. J., 'A map analysis of United States airline competition: part 1-the development of competition', Jour. of Air Law and Commerce 25, 1958, pp.121-47.

Taaffe, E. J., 'A map analysis of United States airline competition: part 2-competition and growth', Jour. of Air Law and Commerce 25, 1958, pp. 402-27.

Taaffe, E. J., 'Trends in airline passenger traffic: a geographical case study', A. A. A. G. 49, 1959, pp.393408.

Taaffe, E. J., 'The urban hierarchy: an air passenger definition', Econ. Geogr. 38, 1962, pp. 1-14. 
地図化や計量的手法を適用して航空流動パター ンの導出やその解明を試みてきた。村山〔注3) 339頁】が指摘するように, Taaffe の一連の研究 は，航空地理学を交通地理学の一分野として確 立させるのに多大な役割を果たした。また，こ の時期の研究として注目される今一つの研究は, Sealy の「航空地理学」と題する著作である。 な和，この時期汸けるわが国の研究としては， 有末杰や奥野がある。

初期の航空地理学の研究論文の少なさに比較 して, 近年においては数多くの研究論文が発表 されて抒り, 航空地理学が交通地理学の中での 主要な地位を占めるようになってきた観すらあ る。この様な傾向は近年に和ける航空交通の急 速な発達と密接に関係しているが，アメリカに おいては1978年の航空会社規制緩和法(以下簡単 に緩和法または規制緩和法という）の制定もこの 傾向の要因の一つになっていると考兄られる。 この法律は，これまで約40年間続いたアメリカ の航空会社に対する規制のいっさいを排除しょ うとするもので, 航空会社並びに地域に与える インパクトは多大なものがあった。

規制緩和法及びそのインパクトについては, 地理学のみならず経済学, 社会学, 政治学, 法 学などいろいるな分野に执いて研究がなされて いる。もっとも関心の高い研究テーマの一つは,
規制緩和が小都市への航空サービスに如何なる インパクトを与えたかというものであって，こ れは規制緩和法の制定後, major p national などの大手航空会社が採算性の悪い小都市への 路線を整理することが予想され，事実それが実 施されたことによる。この範疇にはいる主な研 究としては，102の小都市を対象に免許航空 会社のノンストップ便の変化などを考察した Stephenson and Beier, Iowa 州への航空サー ビスの変化を論じた Sanden, 小都市への航空 サービスの補助についての Addus, コミュー ターの安全性の変化を主に論じた Oster and Zorn, 規制緩和と小都市への航空サービスの継 続の問題を扱った Havens and Heymsfeld，合 衆国の南東部地域を対象に緩和後にピードモン ト航空によるサービスを停止された小都市への 航空サービスを考察した Maraffa and Kiel の 研究などがある。

西岡・宮城はわが国で緩和法を研究した数少 ない研究の一つで, 航空サービスの大都市への シフトの結果, 大都市の地位が一層向上し, 都 市の階層序列がより進んだことを明らかにした。 この他の研究としては，航空会社の利潤と緩和 後の hub and spoke 方式の採用との関係を論 じた Toh and Higgins, 緩和法の評価はサー ビスを受ける立場の違いにより異なることを論

5) Sealy, K.R., 'The Geography of Air Transport, London: Hutchinson, 1957.

6）有末武夫「わが国に和ける 航空交通と遠距離旅客列車の運行一本邦旅客交通の地域的考察」, 東京教育大学地理学研 究報告 $1 ， 1957,1$-20頁。

7）奥野隆史「民間国内航空交通について」，地理 9-6，1964，7-13頁。

8) Stephenson, F.J. and Beier, F.J., 'The effects of airline deregulation on air service to small communities', Transportation Journal 20, 1981, pp. 54-61.

9) Sanden, T. G., 'Changes in air services available to Iowan: 1978-1982', Geographical Perspectives 52, 1983, pp. $13-23$.

10) Addus, A.A., 'Subsidizing air services to small communities', Transportation Quarterly, 1985, pp. 537-552.

11) Oster, C. V. Jr. and Zorn, C.K., 'Airline deregulation, commuter safety, and regional air transportation', Growth and Change, 1983, pp.3-11.

12) Havens, A.I. and Heymsfeld, D. A., 'Small community air service under the airline deregulation act of 1978', Journal of Air Law and Commerce 46, 1981, pp.641-686.

13) Marrafa, T.A. and Kiel, D., 'Air service to cities abandoned by Piedmont Aviation since deregulation', Southeastern Geographer 25-1', 1985, pp. 16-29.

14）西岡久雄・宮城真宏「米国の航空規制緩和下に特ける航空 サービスの大都市へのシフト」，青山経済論集 37 一, 1986, pp. 41-68.

15) Toh, R.S. and Higgins, R.G., "The impact of hub and spoke network centralization and route monopoly on domestic airline profitability', Transportation Journal 24-4, 1985, pp. 16-27. 
じた Zibbel, 緩和後に护ける航空運賃，スケ ジュール，並びに航空代理店の変化を考察した Eno Foundation の研究などがある。

さて，地理学サイドから規制緩和を捉えると き, 研究の中心課題の一つは, 緩和法による合 衆国の結節地域構造の変化ということになる。 この様な視点から既往の研究を概観したとき， このテーマを論じているのは筆者の知る限り西 岡と宫城のみであるが，彼らは合衆国全体を対 象とした結節地域構造を求めてその変化を考察 しているのではない。そこで本研究では, 航空 旅客のＯD表を用いて規制緩和前後の結節地域 構造を求め, 規制緩和法がアメリカの都市の結 節地域構造に及ぼした変化を明らかにする。こ れが本研究の主要な目的である。さらにこの 様な変化は主に規制緩和後の hub 間の競争に よるとの認識のもとに，限定的ではあるが太平 洋北西部の 3 州を例にとり，各 hub の航空旅 客の発生集中交通量の規制緩和前後の変化を求 める。そしてこの変化が，主に各 hub の和か れた，他の hub との相対的な位置関係から生 じる競合によると仮定し, 変化を規定する地理 的要因を明らかにする。これが本研究の副次的 な目的である。

\section{II 研究資料と研究方法}

本研究で使用した主な資料は，CA B (Civil Aeronautics Board, 合衆国民間航空局）が発行し
た国内航空旅客の O D 表である。このデータは アメリカの 全免許航空会社が実施した 乗客の 10\%のサンプル調査の結果にもとついて和り, hub 間の OD 交通量を示している。本研究で 使用したのは，航空規制緩和の前後比較を行い たい目的から，緩和前は 1978 年 9 月 30 日を最 終日とする過去 1 年間のデータ，緩和後は1983 年12月31日を最終日とする 1 年間のデータであ る。

ところで hub とは, 後述するように空港を 含む都市 (航空都市と呼ばれる) のことであり， 乗降客数により 4 段階 (Large, Medium, Small, Non $\mathrm{Hub})^{20)}$ に区分されている。本研究で対象と したのは Small 以上の hub であり，これらの hub 間の O D 航空旅客数を解析の基礎的なデー タとした。ただし，New York と Newark の ように別個の hub と定義されていても，同一 の都市圈と見なした注らが良い場合にはこれ らを1つの hub に纆めた。また Alaska 州と Hawaii 州は除外した。この結果, Large hub 25, Medium hub 32, Small hub 50, 合計 107 の hub が考察対象となった（第1図参照）。 また，航空旅客数の伸びと人口数の伸びとを比 較する際，人口に関するデータを用いたが，こ れは国勢調査によった。

研究の第 1 の方法は，各 hub に和汀る規制 緩和前後に和ける航空旅客の発生集中交通量の 変化率 (1978年值に対する1983年值の割合)を求め,

16) Zibbel, M., 'Airline deregulation-good, bad or difficult ?', The Geographical Bulletin 24, 1983, pp. 11-20.

17) Eno Foundation, 'Transportation in an area of deregulation', Transportation Quarterly, 1985, pp.171-184.

18）本研究で対象としている航空規制緩和とは関係ないが，わが国に打ける航空地理学研究には次のよらなものがある。 井田仁康「日本に持ける国内航空旅客流動の地域的パターンとその発生要因」, 新地理31-3, 1983, 1-12頁。 大原久和「航空交通に扣恀る空港論」, 神戸大学教育学部研究収録 $52,1974,17-38$.

大原久和「航空交通に挌ける空域問題一航空地理学研究の一課題として」, 地理評50, 1977, 290一98頁。 坂本英夫「沖縄県内の二重辺境性克服と農業の集約化」, 奈良大学紀要13，1984，24-37頁。 高橋良宣「空港機能と地域開発」, 地域学研究13，1982，45-55頁。 西岡久雄「臨空産業の立地について(1)」，青山経済論集33-2，1981，109-35頁。 西岡久雄「小型航空拄よび臨海工業一臨空産業の立地について(2)」，青山経済論集35-1，1983，74-102頁。 西岡久雄「臨空産業及び臨空工業一臨空産業の立地について(3)」, 青山経済論集35-2，1983，105一-33頁。

19) Civil Aeronautics Board, 'Origin-destination survey of airline passenger traffic-domestic', third quarter, 1978.; fourth quarter, 1983.

20）hub の区分については第 3 章第 2 節で詳述する。

21) U.S. Department of Commerce, 'Statistical abstract of the United States', 1979, pp.939-944.; 1986, pp.871-876. 


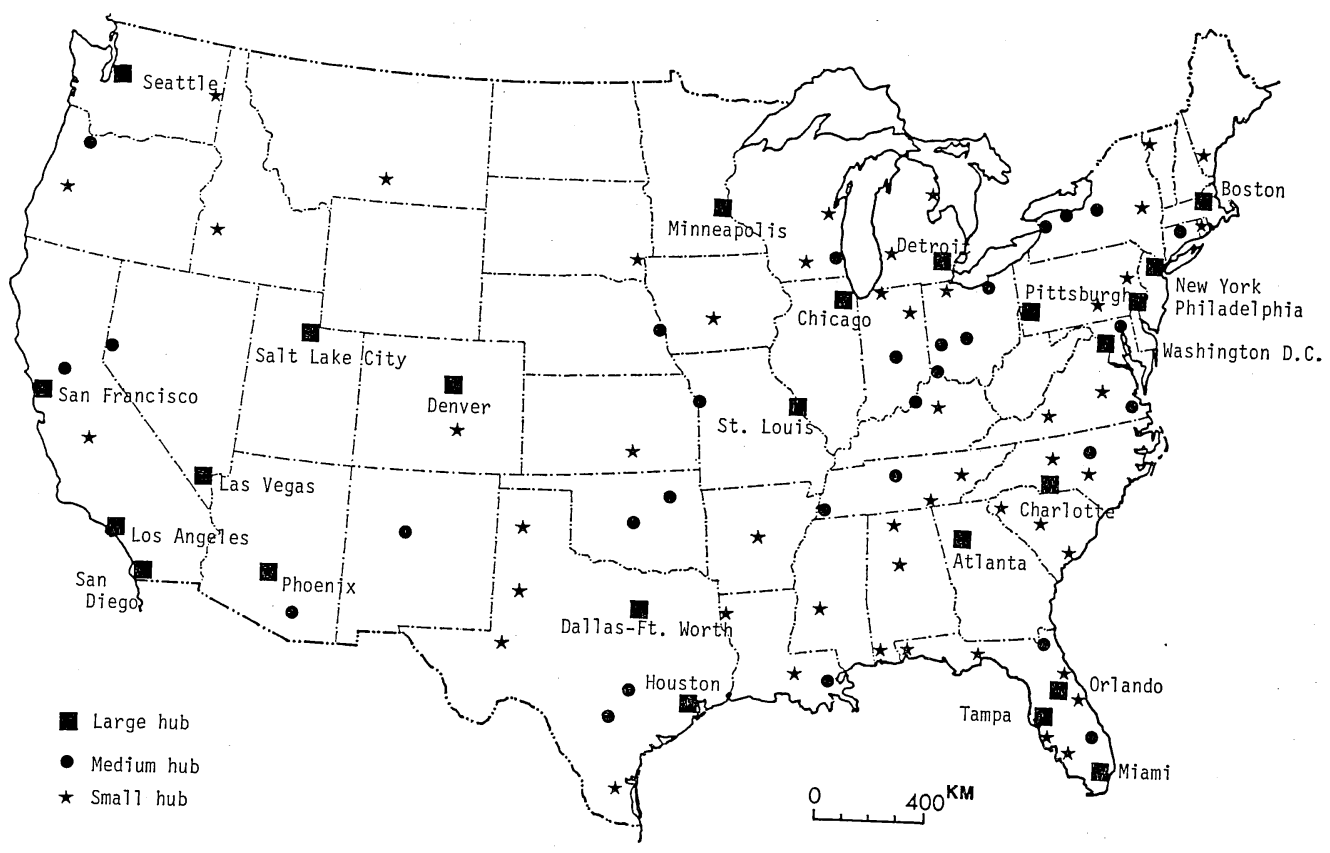

第1図 アメリカ連続大陸部の hub (1983年)

これを図化することにより変化の地域差を把握 しょうとするものである。ところで発生集中交 通量は, 当然のことながら地域の人口数の変化 に左右される。本研究では，規制緩和が各 hub の発生集中交通量に与光た影響を把握したいの で，できる限り人口数の変化の影響を取除くべ く, 次式で示す人口の変化を考慮した発生集中 交通量の変化率を求めた。

$\left(\frac{\text { 発生集中交通量 }(1983)}{\text { 集中交通量 }(1978)}-\frac{\text { 人口 }(1983)}{\text { 人口 }(1978)}\right) \times 100$ この值が正となれば人口数の伸び以上に発生集 中交通量の伸びが高いことを示し，負ならばそ の逆の関係を示す。

研究の第 2 の方法は, Nystuen and Dacey の提唱したグラフ理論法を航空旅客のＯD表に 適用して結節地域構造を把握しようとするもの である。規制緩和前後についてこれを求め, 規 制緩和がいかにアメリカの航空旅客からみた結 節地域構造に影響を与えたかを考察する。
第3 の研究方法は, 対象地域を太平洋北西部 の 3 州 (Washington, Oregon, Idaho) にとり, 各 hub の規制緩和前後の発生集中交通量の変 化の要因分析を重回帰分析を用いて行和らとす るものである。各 hub に护ける交通量の变化 を規定する要因は数多く考えられる。本研究で は，これらの変化が主に規制緩和後の hub 間 の競合によるものであり，その競合は hub の 置かれた地理的位置関係に主に規定されると考 えた。そこで発生集中交通量の変化率を従属変 数とし，hub の置かれた地理的位置関係を表 す変数を独立変数として， Stepwise 法の変数 増減法を用いて重要な変数の抽出を行い, 発生 集中交通量の変化を規定する要因を明らかにす ることを試みた。

\section{III 航空会社規制緩和と航空旅客の変化}

（1）航空会社規制緩和法 アメリカ議会は， 1978 年 10 月, 航空会社規制緩和法案 (Airline

22) Nystuen, J.D. and Dacey, M. F., 'A graph theory interpretation of nodal regions', Papers, the Regional Science Association 7, 1961, pp. 29-42. 
Deregulation Act of 1978) を通過させた。この法 案は, 国内航空会社のうち幹線航空会社 (trunk lines) と地方航空会社 (local service lines) 飞対 する各種の規制と保護を廃止しょうとするもの でこれまで40年間続いた1938年制定の民間航 空法 (The Civil Aeronautics Act) の廃止を意味 するものであった。この規制緩和法については， 宮城, Brenner and et al., 西岡・宮城などに すでに詳しいので，ここでは簡単にその概略を 説明するのみにする。

規制緩和法制定以前に打いては，航空会社は 4 段階に識別することができる。すなわち，高 密度・長距離路線を主に運航する幹線航空会社 (trunk lines), 比較的短距離 の小都市と大都市 間を主に運航する地方航空会社 (local service lines), 州内の運航のみを行ら州内ジェット航 空会社 (intrastate jet lines), 小型のピストン, ターボプロップ機を用いて短距離間のみ運航す るコミューター航空会社 (commuter airlines) の 4 階層である[注24)17頁〕。国内航空会社は一般 に, 路線の開設や変更に際してCABの認可を 必要としたが，州内ジェット航空会社は州間の 運航を避けることにより，またコミューター航 空会社は30座席以下の航空機を用いることによ り，CABの路線認可を必要としなかった。

幹線航空会社と地方航空会社は, 路線の開設 ・変更にはＣABの認可を必要としたが，その ためには“自社が申請した路線運航に適してい て，実行の意思がありかつその能力があるとい らこと，さらにその路線運航は公共の便益に供 するとともに住民の側からのニーズも高いこ と”をC A B に確信させる必要があった〔注24) 4 頁)。このような認可取得は一般に容易ではな く, その手続きに長時間を要したため, 航空会
社間の自由競争を大きく阻害する要因となり, これが経済学者や経済人からの各種の規制と保 護の廃止を求める運動を生み, 規制緩和法の制 定へとつながった。

規制緩和法制定後は，国内航空に対する規制 は徐々に廃止され，1981年12月31日までには大 部分の規制が廃止された。この結果, 各航空会 社は路線の開設・変更・廃止が自由になり, 大 手の航空会社 (緩和法制定後の分類では major と national) は採算性の悪い小都市へのサービスを 縮小ないし廃止し, 主に高密度・長距離路線へ 移行し, 小都市への航空サービスは主にコミュ ーター航空会社によってなされることとなっ た。規制緩和後に和けるこのような変化は当初 から予測されて和り，連邦政府は小都市への一 定の航空サービスを維持する目的で新しいプロ グラムを設けた。それは，緩和法制定前に航空 サービスを受けていた小都市に対して必須航空 便 (essential air service) を算定し, 補助なくし てこの水準を維持できない場合は, 航空会社に 対して補助を与えるといらもので，1988年まで の10年間保証するプログラムである。このよう な連邦政府の補助にも関わらず，大都市と小都 市間の航空サービスに従来以上の差が生じ，西 岡・宮城〔注14〕63頁〕が指摘するように都市の階 層序列化が一層進展した。

規制緩和は航空会社のレベル間の競合にも変 化を及ぼし，かつての幹線航空会社の輸送人員 のシェアーを $90.8 \%$ (1978年) から80.5\% (1983 年）へと低下させ，一方かつての地方航空会社 のシェアを $6.5 \%$ から $10.2 \%$ レ上昇させた 〔注24)18頁】。しかし，少数の大手の幹線航空会 社による市場の支配という構造は依然として不 変である。

23）宮城真宏「米国の航空会社規制緩和法の下に拈ける第 3 レベル航空会社の育成と規制の強化」, 琉球大学教育学部紀 要28, 1984, pp. 103-121.

24) Brenner, M.A., Leet, J. O. and Schoott, E., 'Airline deregulation', Eno Foundation for Transportation, 1985.

25）緩和法制定以後， CA B は航空会社をその年間売上額により, major airlines, national airlines, regional airlines に分類した。これは同法制定以前の trunk airlines, local airlines, commuter airlines にほぼ相当する。 
(2)hub の種類と hub and spoke 方式 連 邦航空庁 (Federal Aviation Administration) は各 空港の航空旅客数のアメリカ全体のそれに占め る割合を基準として，全国の空港を 4 分割して いる。すなわちそれは， large hub（全航空旅客 数の $1 \%$ 以上), medium hub (0.25 0.99\%), small hub (0.05 0.24\%), non hub (0.05\%未 満)の 4 種類である。1978年と1983年 (かっこ内 の数字で示す) に和ける hub の数（すなわち航空 サービスを受ける空港のらち non hub を除いた数) は157 (121) で，その内訳は large hub 25(26), medium hub 39 (36), small hub 93 (59) で あり，これは航空サービスを受ける 620 (408) の全空港 (non hub を含む) の27.6\% (29.4) に あたる。一方これを航空旅客で見ると，hubの 全体に占める割合は $96.8 \%(97.4)$ であり, non hub はわずか $3.2 \%(2.6)$ である。96.8 \% (97.4) の内訳を見ると, large hub は 68.3 $\%(72.8)$ と全体の 3 分の 2 以上を占め, medium hub 18.3\% (17.8), small hub 10.2\% (6.8) となっている。

両年次に於ける hub に関する諸数值を比較 することにより，規制緩和がアメリカ諸都市に 及ぼした影響の概略を把握することができる。 両年次に和仔る顕著な差異は, 定期航空サービ スを受ける空港の数が大幅に減少したことであ り, non hub の多くが規制緩和によって航空 サービスを失ったことが解る。さらにこの結果 として, large hub の重要性がより一層高まっ たことも指摘できよう。 major や national な などの主要航空会社は, 規制緩和後にこれに対 応すべくいくつかの戦略を採った。その一つは 既に指摘した不採算路線の切捨て之高密度 ・長 距離路線へのシフトであるが，いま一つの重要 な戦略の変化は, 従来の都市間ノンストップサ ービス (point-to-point non stop service) から hub and spoke 方式の大幅な採用である。
この方式は都市相互を直接に連結するのでは なく，その中間に大きな hub を置きここで乗 客を乗り換えさせる方式である(第 2 図)。

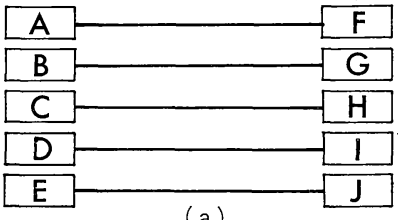

(a)
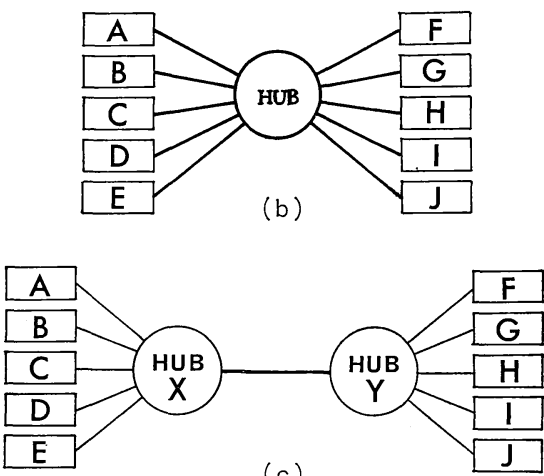

(c)

第 2 図 hub and spoke 方式

(a) 都市間ノンストップサービス

(b)(c) hub and spoke 方式

$A \sim J$ : 各都市

出所 : Brenner, M. A. and et. al "Airline deregulation" ENO Foundation, 1985, p. 83 (ただし，図(c)は筆者によ

る)

第 2 図 $\mathrm{a}$ と，第 2 図 b ，c c 比較するとわか るように，この方式によると同数の航空機で都 市ペアが 5 から35に增加するとともに，各ルー トでの航空旅客数の増加も同時に達成できる。 特に第 2 図cに示す様に 2 つの中心的 hub が ある場合には，2つの中心 hub 間の航空旅客 数は極めて多くなり，従ってこの間には大型の 航空機が効率的に投資できることになり，運賃 もこの区間では極めて安くなる。

第 3 図は, American 航空会社の Dallas-Ft. Worth ヘのノンストップ便の規制緩和前後を 比較したものである。規制緩和後に hub and spoke 方式が大幅に採用されたのがこの図から 解るが，ちなみに, American の航空機の総離

26) $\mathrm{CAB}$, 'Airport activity statistics of certificated route air carriers', 1978, 1983. 

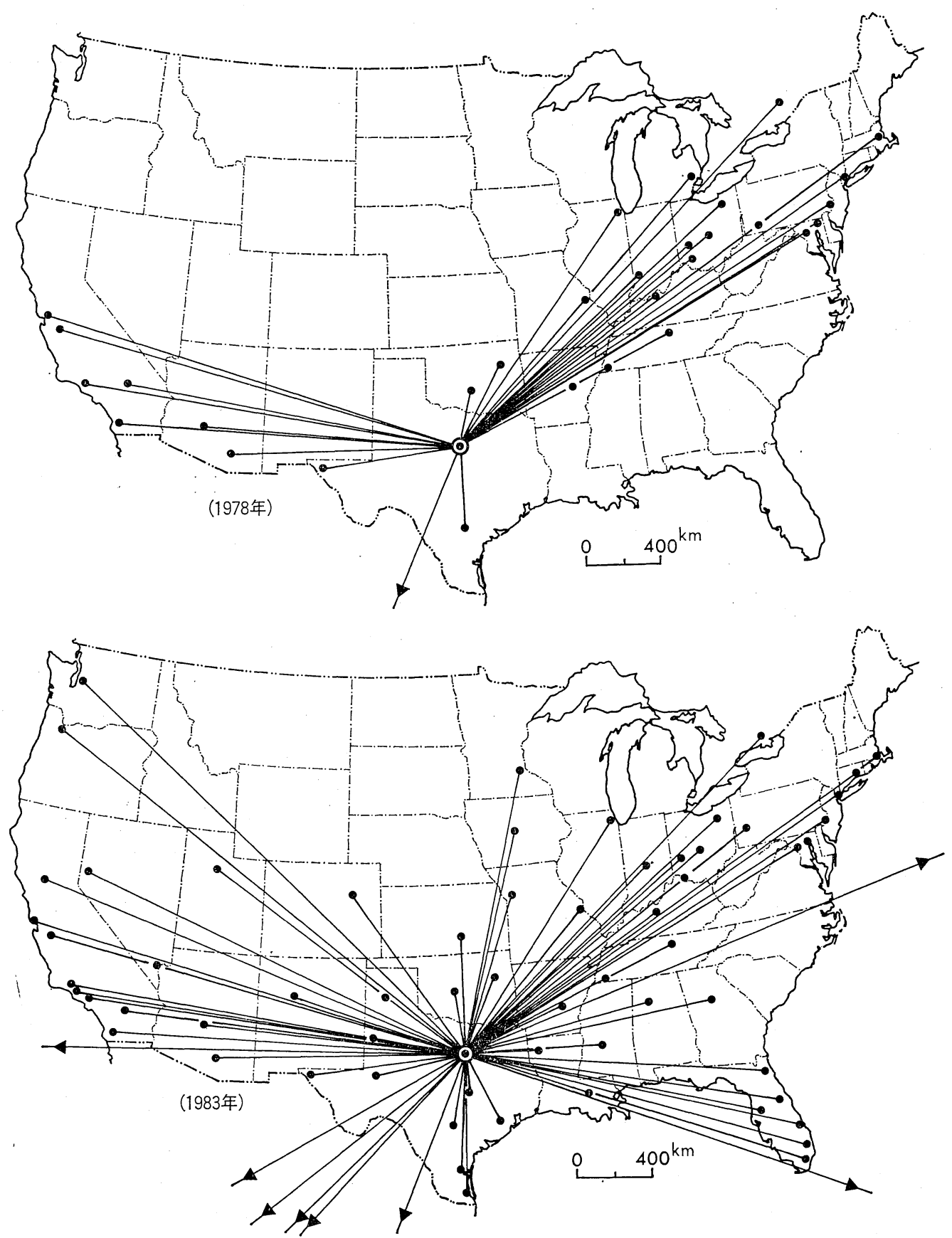

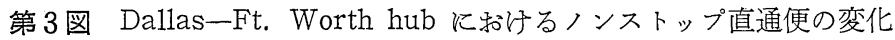

出所: Brenner, M. A. and et. al "Airline deregulation", ENO Foundation, 1985, p.79.

注）図中の黒丸は hub を示す。

陸回数のらち Dallas-Ft. Worth が占める割合 は，1978年の $11.2 \%$ か 1983年の $28.6 \%$ と大 幅に増加した〔注14〕60頁〕この一方で，規制緩
和後は中小都市間を結ぶノンストップ直通便が 大幅に減少した。

航空規制緩和は航空運賃にも大きな影響を与 


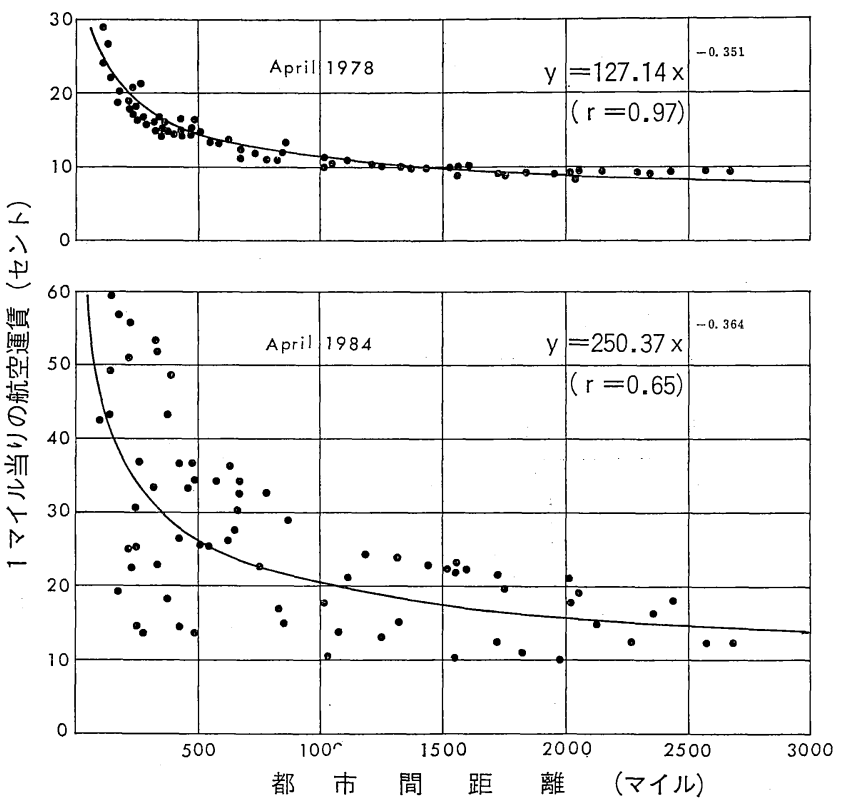

第 4 図 1 マイル当り航空運賃と都市間距離の関係の変化 出所 : Brenner, M.A. and et. al "Airline deregulation" ENO Foundation, 1985, p. 37.

注）回帰式は筆者算定。

党，規制緩和前に注济成り立っていた距離聥減 運賃の傾向を完全に崩壊させた。これは，hub and spoke 方式の採用による主要なルートで の競争の激化による運賃の低下，採算性の悪い ルートに拈ける大手航空会社からコミューター 航空会社への運行の移行とそれにともなら運賃 の上昇など，いくつかの要因が作用した結果で ある。第 4 図は規制緩和前後の単位距離当りの 運賃と都市間距離との関係を表したものである。 規制緩和前に扔いては，両者の間には右下がり の顕著な関係（両者対数をとると直線関係）が見 られ，相関係数は 0.97 と極めて高い。これに対 して規制緩和後に执いては，マクロ的には距離 莪減の傾向が見られるもののその関係は明確で なく，相関係数も0.65へと低下した。

(3)航空旅客の变化 まず最初に, 規制緩和 前後の hub タイプ別の 航空旅客の発生集中交 通量，並びにその変化率 (1978年值に対する1983 年值の割合）を求め, hub タイプと变化率との 関係に注目してみた（第1表)。small hub は,
第 1 表 hub タイプ別発生集中交通量の変化

\begin{tabular}{|c|c|c|c|c|c|}
\hline \multirow[b]{2}{*}{ hub } & \multicolumn{2}{|c|}{ 総発生集中交通量 } & \multicolumn{2}{|c|}{$\begin{array}{l}1 \mathrm{hub} \text { 当り平均 } \\
\text { 発生集中交通量 }\end{array}$} & \multirow{2}{*}{$\begin{array}{c}\text { 変化率 } \\
\\
(1983 / \\
1978)\end{array}$} \\
\hline & 1978年 & 1983年 & 1978年 & 1983年 & \\
\hline rge & $8,826,210$ & $11,815,200$ & 353,048 & 472,609 & 133.9 \\
\hline medium & $2,848,060$ & $3,422,420$ & 89,002 & 106,951 & 120.2 \\
\hline small & $1,368,290$ & $1,361,530$ & 27,366 & 27,231 & 99.5 \\
\hline
\end{tabular}

総発生集中交通量, $1 \mathrm{hub}$ 当り平均発生集中交 通量とも1983年值が1978年值を下回っておう, その変化率は99.5である。これに対して， large hub, medium hub はともにこの 5 年間で 増加を示しているが，増加率は前者（133.9）が 後者（120.2）を大きく上回っている。ちなみに, 3 つのレベルの hub 全体の変化率は 127.3 で あるが，この平均值を上回るものは large hub のみである。従って，規制緩和は規模の大きな hub ほどより大きなプラスの効果（すなわち高 (增加率)をもたらしていると指摘できよう。

次に，規制緩和前後の各 hub 飞和㺭る航空 旅客の発生集中交通量の変化を見るため，1978 


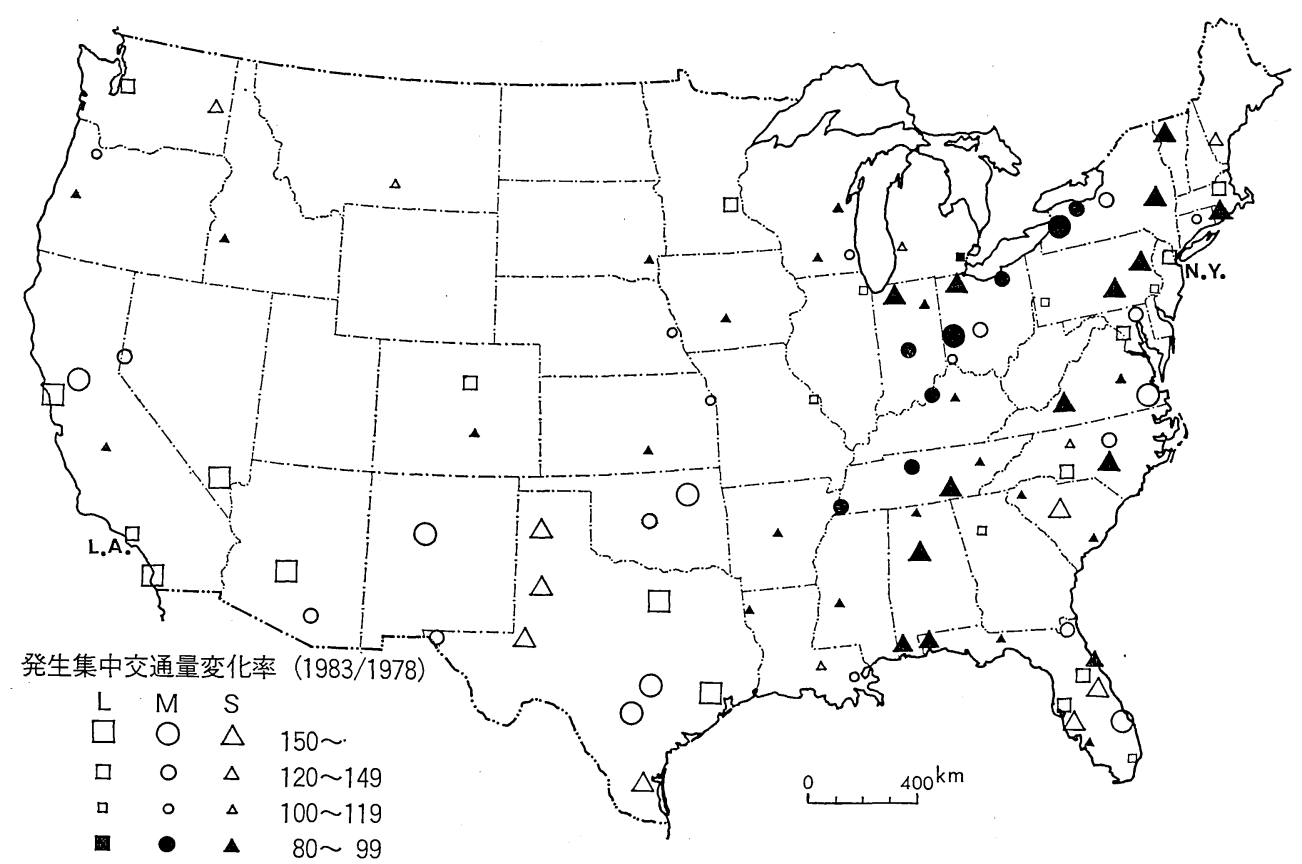

第5 図 hub 亿括汗る発生集中交通量の変化率

注) L: Large hub $\mathrm{M}$ : Medium hub $\mathrm{S}:$ Small hub

年值に対する 1983 年值の割合（\%)を求めこれ を図化した（第 5 図）。この図を空間的にみると， 東部に和汀る発生集中交通量の増加と減少の hub の混在，中西部と西部に和ける増加の hub の卓越を認めることができる。hub のレ ベルという視点でこの図を見ると， large hub

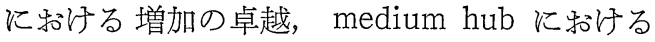
増加と減少の混在，そして small hub での 減 少の卓越が顕著である。ちなみに， large hub でこの間発生集中交通量の減少を見たのは唯一 Detroit であって，それ以外は程度の差こそあ れ全て発生集中交通量の増加を見ている。州別 そみて顕著な特徵を示すのは, 中西部南部の Texas, New Mexico, Arizona などの諸州で あって，これらはいずれの hub レベルにおい ても大幅な発生集中交通量の増加を見ている。

ところで，発生集中交通量は地域の人口数に 左右される。そこでこの影響を取り除くべく， 研究方法のところで示した，人口の変化を考慮 した発生集中交通量の変化率を求めこれを図示
した（第6図)。これを空間的にみると次のよう な特徵が指摘できる。1）東部沿岸諸州に括け るプラスの変化率とマイナスの変化率を示す hub の混在，2）マイナスの変化率を示す Indiana, Kentucky, Arkansas, Tennessee, Louisiana, Mississippi, Alabama などの中央 平原の諸州，3）全ての hub に预いてプラス の変化率を示す中西部南部の Texas, New Mexico, Oklahoma の諸州, 4) small hub 以 外の hub に叔いてプラスの変化率を示す中西 部中北部と西部海岸部。

次に hub レベルという視点で変化率を見る と, large hub に拉けるプラスの変化率の卓越, medium hub に和将るプラスの変化率とマイ

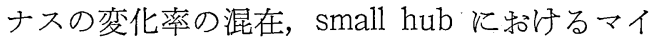
ナスの変化率の卓越が指摘できる。これらの hub の変化は規制緩和にのみ起因するのでな く，人口や経済活動の変化など他の要因にも左 右されよう。しかし，期間が 5 年間という短期 間を考えると，規制緩和はこの変化の重要な要 


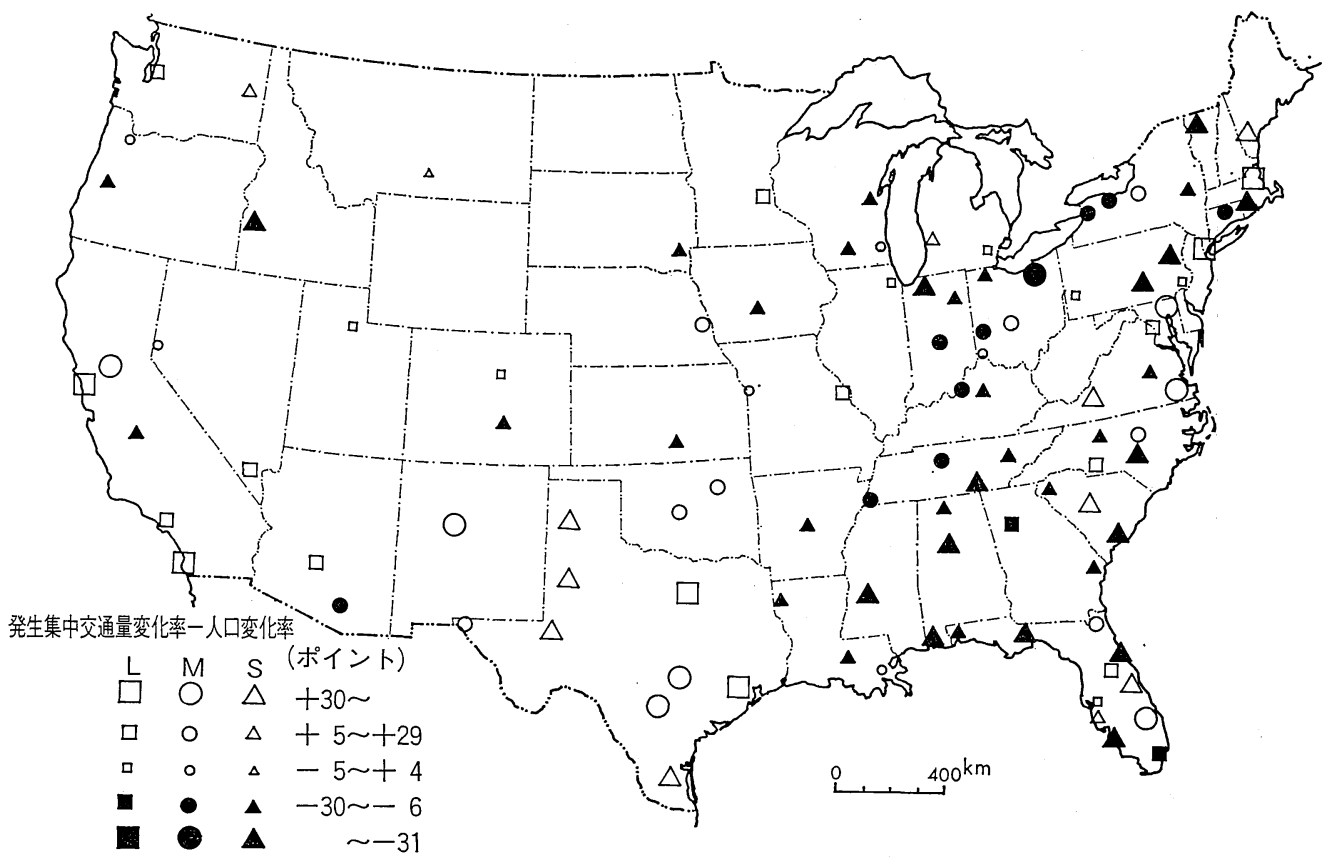

第6図人口の変化を考慮した発生・集中交通量の変化率

注) L: Large hub $\mathrm{M}$ : Medium hub $\mathrm{S}$ : Small hub ポイントとは, 発生集中交通量变化率 (1978年值に対する1983年值の 割合(\%)) から人口変化率 (1978年值に対する1983年值の割合 $(\%))$ を引いた值である。

因の一つと考えてょく，従って，規制緩和は大 規模な large hub のより一層の成長，逆に小 規模な small hub のより一層の衰退に寄与す るところ大であったと見てよい。

(4) 太平洋北西部における航空旅客の変化と その要因分析 既にみてきたように，規制緩和 後の各 hub の発生集中交通量は, 緩和前のそ れに比べて大きく変化した。この様な変化は, 各 hub のもつ地域性, 航空会社の緩和後の戦 略の変化など多様な要因に起因していると考光 られる。地理学の立場からこの変化をみたとき, 各 hub が置かれた他の hub との 相対的位置 関係（そしてこれに起因する hub 相互間の競合）を 表す要因により，どの程度この変化が説明でき るかは興味あるテーマである。この様な hub
間の競合については，西岡・宮城〔注14)60頁】が， 規制緩和後，人々は従来の近距離にあるhub 指向から，車を利用してょり高い満足が得られ る，より規模の大きい遠くの hub へ出向く, といらパターンが一般化してきたと指摘してい る。

そこで本研究では, 極めて限定された地域で はあるが，太平洋北西部 3 州 (Washington, Oregon, Idaho) の hub (non hub む含む) のうち, 年間発生集中交通量が 1,000 人以上の $16 \mathrm{hub}$ を研究対象として, 発生集中交通量の変化率 （1978年值に対する1983年值の割合：RＣ）を従 属 変数とし，第 2 表に示す 13 変数を説明変数と して Stepwise 法の変数増減法による重回帰分 析を試みた。もとより，わずか 3 州を対象にし

27）この地域を研究対象としたのは，筆者がこの地域に多少認識があることにもよるが，それほど急激な都市発展のない この地域が,できるだけ急激な都市発展による交通量の変化の影響を解析から除きたいといら本研究の目的に合致して いたことにもよる。

28）変数増減法に括ける变数の取り込み，追い出しの基準としては，F=2.0を使用した。この手法については下記が 
第 2 表 説明変数一覧表

\begin{tabular}{|c|c|c|}
\hline 変数番号 & 記 号 & 味 \\
\hline 1 & TR & 当該 hub の発生集中交通量 \\
\hline 2 & D B & 最寄りのより規模の大きい hub への車での移動時間（分） \\
\hline 3 & D S & 最寄りのより規模の小さい hub への車での移動時間（分） \\
\hline 4 & $\mathrm{~TB}$ & 最寄りのより規模の大きい hub の航空旅客の発生集中交通量 \\
\hline 5 & $\mathrm{TS}$ & 最寄りのより規模の小さい hub の航空旅客の発生集中交通量 \\
\hline 6 & DU & 最寄りのより上位のランクの hub への車での移動時間 (分) \\
\hline 7 & $\mathrm{TU}$ & 最寄りのより上位のランクの hub の航空旅客の発生集中交通量 \\
\hline 8 & G 1 & $\mathrm{~TB} \div \mathrm{DB}^{2}$ \\
\hline 9 & G 2 & $\mathrm{TU} \div \mathrm{DU} 2$ \\
\hline 10 & G 3 & $\mathrm{TS} \div \mathrm{DS} 2$ \\
\hline 11 & P O P & 人口変化率 $(1983$ 年值 $/ 1978$ 年值) \\
\hline 12 & B 3 & 車で 3 時間で到達可能なより大きい規模の hub の航空旅客の発生集中交通量の総和 \\
\hline 13 & S 3 & 車で 3 時間で到達可能なより小さい規模の hub の航空旅客の発生集中交通量の総和 \\
\hline
\end{tabular}

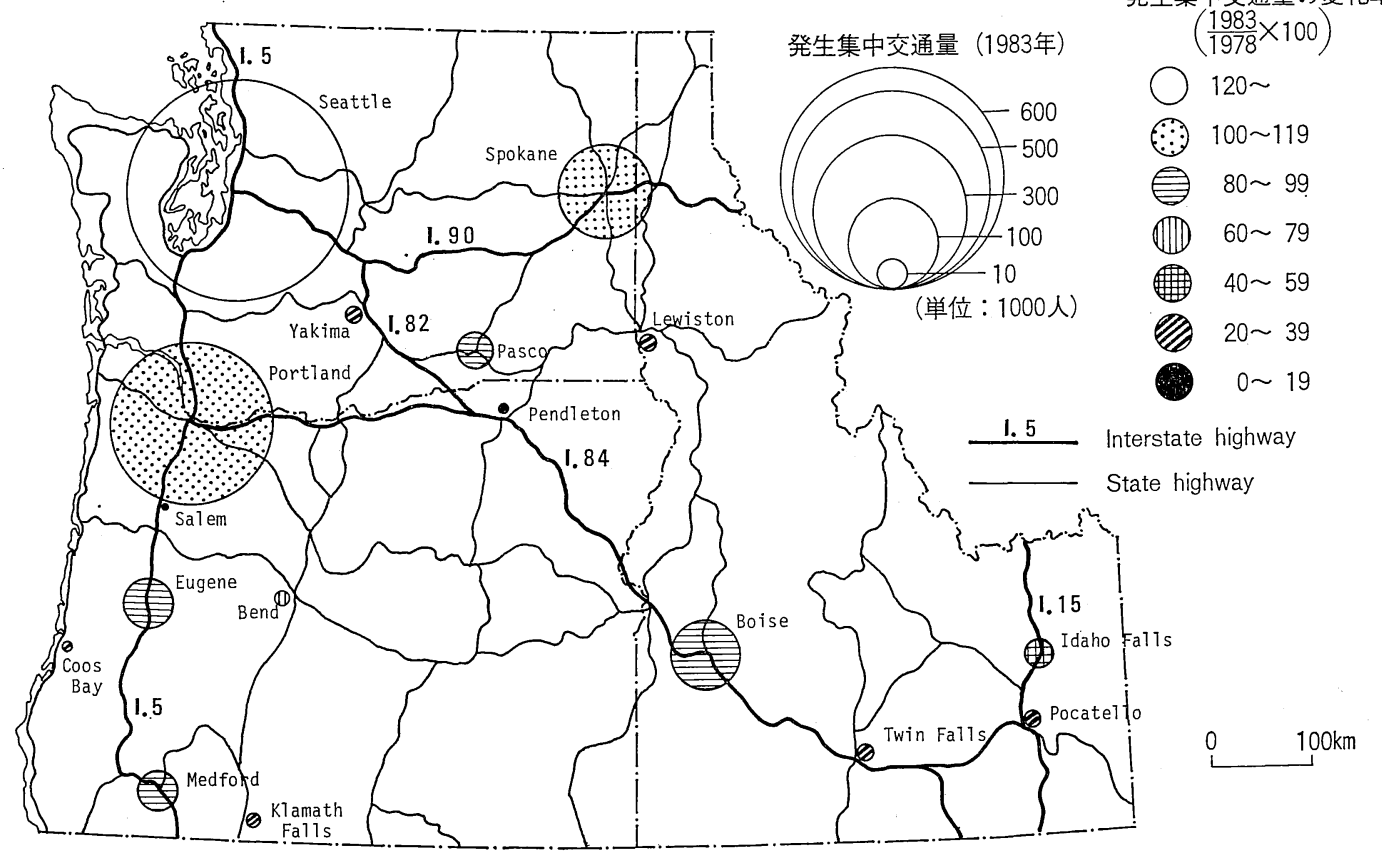

第 7 図 太平洋北西部地域の hub の発生集中交通量とその変化率

たたシけで，前節で指摘したアメリカ全体の変化 を規定する要因を一般化できるとは思われない。 従って，ここでの結果は，あくまで太平洋北西 部地域に限って指摘できることであるが，今後， アメリカ全体について考察する際の基礎的資料 を提供できるものと考える。

説明変数について若干説明を試みると，T R
は hub の規模を表し，PＯＰは人口変化率を 表す変数であるが，その他の変数は，全て hub の括かれた地理的位置関係を表す変数である。 D B, D S, T B, T S, DU, TUの諸変 数は，最寄りの上位 (下位) の規模（ランク）の hub の発生集中交通量，並びにそれへの移動 時間を表したものである。ここでは，発生集中

$\searrow$ 詳しい。

奥野忠一他『多变量解析法』，日科技連，1971，25-157頁。 
交通量がより大きい hub が当該 hub の近く にあればあるほど，当該 hub の発生集中交通 量の減少率が大きくなると仮定している。G1, G2，Ｇ3 は， 発生集中交通量と移動時間を合 成した変数で，一種の吸引力を表するのである。 B 3 とS3 は, D B D S などの変数が最寄り の hub のみを対象にしているのに対して，車 で 3 時間で移動できる範囲内の全ての hub を 対象とし，例兄ばある大きな hub が周辺の複 数の小さな hub の乗客を奪う可能性を考慮し た変数である。

第 7 図は航空旅客の発生集中交通量とその变 化率を示したものである (第 3 表参照)。Seattle と Portland の large hub はいずれも発生集 中交通量の増加を見ているが，それ以外の hub では Spokane を除くとすべて減少である。 Spokane の増加は, 同 hub がより上位の Seattle p Portland と遠くはなれていて競合 がなく，一方周辺の hub の乗客を奪うことが 可能なためと思われる。減少を示した hub の 中で，最もとの率が大きいのが Pendleton と Salem であり， 発生集中交通量はこの 5 年間 で実に 10 分の 1 以下となり，その変化率はそ れぞれ8.1と 5.4 であった。これは，前者は
第 3 表 発生集中交通量の変化率とその予測值

\begin{tabular}{|c|c|c|c|c|c|c|}
\hline \multirow{2}{*}{ hub 名 } & \multirow{2}{*}{$\begin{array}{l}\text { hub } \\
\text { タイプ }\end{array}$} & \multicolumn{2}{|c|}{ 発生集中交通量 } & \multicolumn{2}{|c|}{ 変 化 率 } & \multirow{2}{*}{ 残差 } \\
\hline & & 1978年 & 1983年 & 実測值 & 予測值 & \\
\hline ssco & $\mathrm{N}$ & 17,351 & 16,117 & 92.9 & 78.6 & 14.3 \\
\hline ookane & S & 98,016 & 114,569 & 116.9 & 108.7 & 8.2 \\
\hline akima & $\mathrm{N}$ & 587 & 3,355 & 35.0 & 26.1 & 8.9 \\
\hline end & $\mathrm{N}$ & 3,304 & 2,254 & 68.2 & 41.3 & 26.9 \\
\hline uge & S & 36,416 & 30,476 & 83.7 & 50.1 & 33.6 \\
\hline $\begin{array}{l}\text { nath } \\
\text { Falls }\end{array}$ & $\mathrm{N}$ & 475 & 1,670 & 30.5 & 32.7 & -2.2 \\
\hline & $\mathrm{N}$ & 21,838 & 18,894 & 86.5 & 53.0 & 33.5 \\
\hline Bend & $\mathrm{N}$ & 3,159 & 659 & 20.9 & 34.0 & -13.1 \\
\hline endleton & $\mathrm{N}$ & 5,573 & 452 & 8.1 & 25.1 & -17.0 \\
\hline alem & $\mathrm{N}$ & 621 & 142 & 5.4 & 19.6 & -14.2 \\
\hline & S & 72,607 & 63,065 & 86.9 & 100.5 & -13.6 \\
\hline Falls & $\mathrm{N}$ & 16,069 & 9,561 & 59.5 & 75.9 & -16.4 \\
\hline ocatello & $\mathrm{N}$ & 10,919 & 2,826 & 25.9 & 40.8 & -14.9 \\
\hline Twin Falls & $\mathrm{N}$ & 10,247 & 3,407 & 33.2 & 33.1 & 0.1 \\
\hline ewiston & $\mathrm{N}$ & 5,912 & 1,188 & 20.1 & 42.9 & -22.8 \\
\hline Portland & M & 303,609 & 340,189 & 112.0 & 123.4 & -11.4 \\
\hline
\end{tabular}

注) hub タイプ $\mathrm{M}$ : medium hub $\mathrm{S}$ : small hub $\mathrm{N}:$ non hub

重回㷌式モデルは次式で示される（変数名については 表 2 参照)

$\mathrm{RC}=10.125+0.157 \mathrm{DB}+0.002 \mathrm{~S} 3$

Pasco, 後者は Portland に非常に接近してい るため，これら上位の hub に乗客を奪われた ためと考觉らる。

第 4 表は変数間の相関係数を示す。発生集中 交通量の変化率 R C と最も相関が高い変数はS 3 , 続いてD B, TRなどであるが, 説明変数 間には相互にかなり高い相関を示すものがかな

第 4 表 変数間相関係数

\begin{tabular}{|c|c|c|c|c|c|c|c|c|c|c|c|c|c|}
\hline 変 数 & T R & D B & D S & T B & $\mathrm{TS}$ & $\mathrm{DU}$ & $\mathrm{TU}$ & G 1 & G 2 & G 3 & POP & B 3 & S 3 \\
\hline TR & & & & & & & & & & & & & \\
\hline $\mathrm{DB}$ & .37 & & & & & & & & & & & & \\
\hline D S & -.31 & -.10 & & & & & & & & & & & \\
\hline $\mathrm{TB}$ & $.74^{* *}$ & .47 & -.19 & & & & & & & & & & \\
\hline T S & .11 & $.57^{* *}$ & -.10 & .17 & & & & & & & & & \\
\hline $\mathrm{DU}$ & .24 & $.75^{* *}$ & -.11 & .19 & $.80 * *$ & & & & & & & & \\
\hline $\mathrm{TU}$ & $.58^{*}$ & .22 & -.23 & $.69 * *$ & .01 & .17 & & & & & & & \\
\hline G 1 & -.01 & -.31 & .27 & .34 & -.26 & -.47 & .22 & & & & & & \\
\hline G 2 & -.03 & -.33 & .27 & .30 & -.32 & -.49 & .33 & $.98^{* *}$ & & & & & \\
\hline G 3 & .14 & .40 & -.44 & .25 & $.68^{* *}$ & .38 & .13 & -.14 & -.16 & & & & \\
\hline POP & -.43 & .16 & .26 & -.02 & -.18 & -.08 & -.04 & .17 & .19 & -.25 & & & \\
\hline B 3 & -.24 & -.43 & .15 & -.06 & -.44 & $-.52^{*}$ & .38 & .44 & $.59^{*}$ & -.29 & .13 & & \\
\hline S 3 & $.86^{* *}$ & .41 & -.46 & $.73^{* *}$ & .25 & .30 & .42 & -.10 & -.17 & .25 & -.06 & -.33 & \\
\hline $\mathrm{R} \mathrm{C}$ & $.62^{* *}$ & $.67^{* *}$ & -.32 & $.61^{* *}$ & .33 & .40 & .30 & -.27 & -.31 & .22 & .16 & -.28 & $.77^{* *}$ \\
\hline
\end{tabular}


りある。そこで重回帰分析に和いて多重共線性 の発生を防ぐため，有意水準 $5 \%$ で有意な相関 のある変数の組合せのらち，どちらか一方を説 明变数群から取り除くことにした。この結果, $\mathrm{TR}, \mathrm{TB}, \mathrm{T} \mathrm{S}, \mathrm{DU}, \mathrm{G} 2, \mathrm{G} 3$ の 6 つの 変数が取り除かれた。そこで残りの 7 つ変数 を説明変数として, stepwise 法の变数増減法 による重回帰分析を適用し, 従属变数をもっと もよく説明する变数群をこの中から抽出した。 最終的には 2 つ変数が有意なものとして抽出 された。

まず第一ステップでは，車で 3 時間で到達可 能なより小さい規模の hub の発生集中交通量 の総和 S 3 が取り达まれ, 第 2 ステップで, 最 寄りのより規模の大きい hub への移動時間D Bが取り込まれた。説明変数がS 3 だけでも相 関係数は 0.772 とかなり高く, これにD Bを加 えるとその值は 0.864 となる。従って, 航空旅 客の発生集中交通量の変化率は, S 3 とD B と いう僅か 2 変数で全変動の約 $75 \%$ が説明できる ことになる。

第 5 表には回帰係数の值を, 第 6 表には分散 分析の結果を示す。重回帰式, 偏回帰係数とも 有意であって，標準偏回帰係数を見るとS 3 が D B より約 $50 \%$ 程重要な変数であることが解る。 従って，1）変化率 R C は, 当該 hub の周辺 により規模の小さい hub があればあるほど， それらの旅客を奪って高くなること，また，2） 最寄りのより規模の大きい hub と時間的に隔 たっていればいるほど，これとの競争を回避で

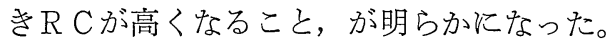

$\mathrm{R} \mathrm{Cが} \mathrm{S} 3$ と D といら 2 つの変数でその変 動のかなりの部分を説明できると言っても，依 然としてこの 2 変数では説明できない部分が約 25\%あり，また個々の hub でみると予測值が 実測値とかなりか梳れている場合がある（第
第 5 表 回帰係数と重相関係数

\begin{tabular}{|c|c|c|c|c|c|}
\hline & \multicolumn{2}{|c|}{ 第 1 ステップ } & \multicolumn{3}{|c|}{ 第 2 ステップ } \\
\hline & \multicolumn{2}{|c|}{ 単回帰モデル } & \multicolumn{3}{|c|}{ 重回帰モデル } \\
\hline & S 3 & 定数項 & S 3 & D B & 定数項 \\
\hline 偏回㷌 & 0.00266 & 31.92905 & 0.00207 & 0.15710 & 10.1251 \\
\hline $\begin{array}{l}\text { 標潗偏回帰 } \\
\text { 数 } \mathrm{b}^{\prime}\end{array}$ & 0.77217 & & 0.60053 & 0.42343 & \\
\hline $\begin{array}{c}\mathrm{b} \text { の標準 } \\
\text { 䛊差 } \mathrm{S}_{\mathrm{b}}\end{array}$ & 0.00059 & & 0.00053 & 0.05672 & 10.26998 \\
\hline $\mathrm{t}$ 值 & 3. $645^{* *}$ & 0.856 & $3.928^{* *}$ & $2.770^{*}$ & 0.986 \\
\hline $\begin{array}{l}\text { 重相 } \\
\text { 関係数R }\end{array}$ & \multicolumn{2}{|c|}{$0.772^{* *}$} & \multicolumn{3}{|c|}{$0.864^{* *}$} \\
\hline 寄与率 $\mathrm{R}^{2}$ & \multicolumn{2}{|c|}{0.596} & \multicolumn{3}{|c|}{0.746} \\
\hline
\end{tabular}

注) ** $1 \%$ で有意

* $5 \%$ で有意

第 6 表 分散分析表

\begin{tabular}{|c|c|c|c|c|c|}
\hline \multicolumn{2}{|c|}{ 変動因 } & 自由度 & 平方和 & 分 散 & 分散比 $F$ \\
\hline 回 & 帰 & 2 & $15,597.6$ & $7,798.8$ & $19.1^{* *}$ \\
\hline 残 & 差 & 13 & $5,308.3$ & 408.3 & \\
\hline 全 & 体 & 15 & $20,905.9$ & $1,393.7$ & \\
\hline
\end{tabular}

注） ** $1 \%$ で有意

3 表参照)。2 5 ポイント以上の残差がある hub は Eugene, Medford, Bend で，何れも実測 值が予測值を大幅に上回っている。即ち，その 置かれた地理的条件では，より大幅な交通量の 減少率が予測されるのにも関わらず，それほど の減少が認められない hub である。これらの hub は何れも Oregon 州の南西部に位置して いるが，これが大幅な残差の原因であるのか， また全く別の要因によりこの残差が生じている のかについては今後に残された課題である。

\section{IV 航空旅客による結節地域構造とその変化}

(1)規制緩和前の結節地域構造 航空旅客の OD表に対して，Nystuen and Dacey のグラ フ理論法を適用して結節地域構造を求めた（第 8 図)。重要な結節地域としては, New York を中心結節点とするものを始め, Chicago, Atlanta, Dallas-Ft. Worth, Los Angeles, San

29）ここでポイントとは，変化率R C（発生集中交通量の1978年值に対する1983年値の割合（\%)）の実測値と予測值の 差の絶対値である。 


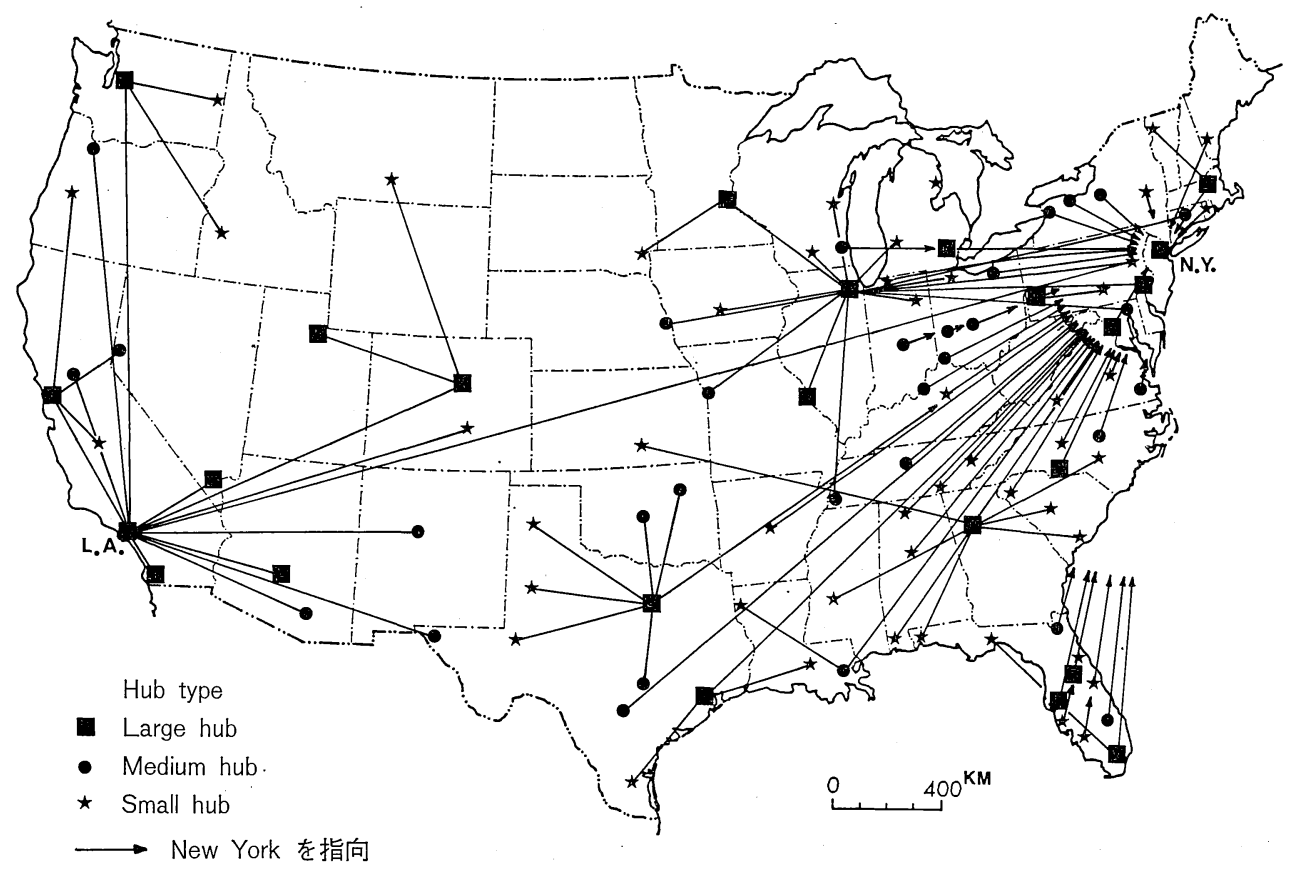

第 8 図 航空旅客による結節地域構造（1978年）

Francisco, Seattle などをそれぞれ中心結節点 とする結節地域群を確認することができる。こ の内最大の結節地域は, New York を中心結 節点とするものであって，東部地域のほとんど 全ての hubを先の支配下に扣いて扣り，その 圈域は極めて広大である。この結節地域のさら なる 特徵は, Chicago, Atlanta, Dallas-Ft. Worth, Los Angeles などの重要な結節地域の 中心結節点を従属させていることである。従っ て，ここには明らかに結節地域の階層構成を認 めることができ，New York は，中間に Chicago やAtlanta などの都市を介して，アメリ カのほとんどの都市をとの支配下に置いている ということができる。例えば， New York は Chicago を支配 し, Chicago はMinnea Polis -St. Paul を, Minnea Polis・St. Paul は Sioux Fallsをそれぞれ支配して抢り，ここに は三段階の階層が見られる。

New York に続いて大きな結節地域は, Los Angeles を中心結節点とするものであって,
San Francisco, Seattle などの主要な都市を初 め周辺の都市を従属させ，西海岸で最大の結節 地域である。この 結節地域はとの中に 6 つの large hubを含んで和り，この点でも New York に比肩しらる圈域である。Idaho 州 Boise と Washington 州 Spokane は Seattle を指向して一つの小さな結節地域を形成し，そ の中心結節点 Seattle は Los Angeles を指向 しているので，ここにも結節地域の階層構成を 認めることができる。従って，最上位の中心結 節点 New York を考慮にいれると，三重の結 節地域の階層構成が確認できる。

Chicago も一つの結節地域を構成するが, その圈域は同市から西部ないし南部に広がり， 東部ではごく近隣の都市しか文の支配下にいれ ていない。これは, New York の勢力が Chicago の近くまで及んでいるためである。南部 の Dallas-Ft. Worth は，人口規模の割にはか なり大きな結節地域の中心結節点となっている が，これは New York や Los Angeles など 
の大都市から相互に距離を隔たっていて，両市 の勢力が余り及ばないためと考えてよい。San Francisco, Seattle, Denver は，2，3の小 都市を従属させてそれぞれ結節地域を構成して いるが，これらはいずれも Los Angeles を指 向して和り，それゆ光1ランク下位の結節地域 である。

この図からはまた，交通の傘 (traffic shadow) 効果も顕著に読み取ることができる。即ち, New York の周辺の Boston, Philadelphia, Washington D.C. などは，その人口規模の大 きさにも関わらず結節地域を構成してその中心 結節点となっていない。これは, New York の勢力の大きさとそれへの距離の近さのために, 独自の圈域が構成できないためである。陸上交 通機関との競合のため, 近距離の hub を指向 せずより上位の遠くの hub を指向する傾向も みられる。Indiana 州 South Bend は好例で
あり，近隣の Chicago を指向せず New York を指向している。Philadelphia が New York でなく Chicago を指向しているのも同様な例 である。

(2)規制緩和後の結節地域構造 緩和後の結 節地域構造については，緩和前とのそれと比較 して，主に変化した点に着目して考察を行う (第 9 図)。ところで Miyagi ${ }^{30)}$ は，本研究と同様 なデータと手法を用いて，アメリカに和けるプ ロペラ機からジェット機への新技術の移行が,

諸結節地域の階層構成に如何なる变化を及ぼし たかを考察した。その結果, 新技術の移行によ っても重大な変化はもたらされていないと結論 し, 諸結節地域乞れぞれの持つ相対的地位は安 定し，第 1，2，3 階位それぞれのセンターの 相対的重要性もなんら変化なく, 最低位のセン ターですら僅かな変化しか見られなかったこと を明らかにしている。Miyagi の研究と比較し

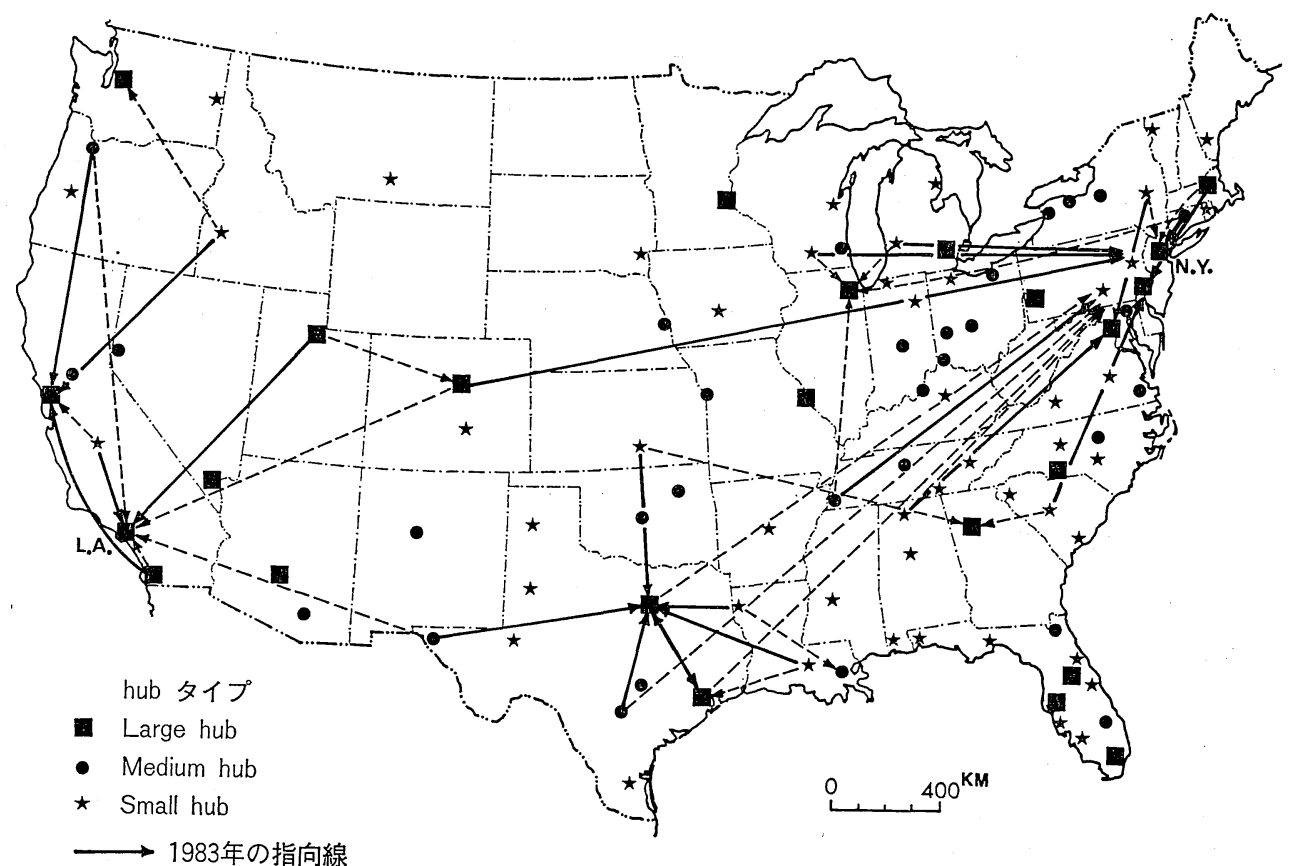

第 9 図 航空旅客による結節地域の構造（1983年）

注）1978年と比較して变化したもののみを示す

30) Miyagi, M., 'Impact of jet aircraft on the airline network of the United States, 1959-1965', Columbus: Ohio State Univ., Ph. D. Thesis, 1969. 
て，本研究に扔ける変化の程度がどのくらいか を正しく指摘するのは困難であるが，研究対象 とした $107 \mathrm{hub}$ のち，5分の 1 以上に当た る $24 \mathrm{hub}$ がその 対地第 1 位指向地を変更し ていることを考えると, 航空規制緩和は, 航空 旅客からみた結節地域の構造にかなりの变化を 及ぼしたと考劣てよいであろう。

もっとも顕著な変化は Dallas-Ft. Worth に 执いてみられ，その周辺に位置しこれまで New York や Los Angeles などを指向してい た hub から新たに指向されるようになりよ り一層明確な結節地域を構成するようになって きた。Dallas-Ft. Worthを新たに指向するよ らになった hubは, Kansas 州 Wichita, Texas 州 El Paso, San Antonio, Houston, Louisiana 州 Shreveport, Baton Rouge の 6 hub であり，これは指向地を変更した全 hub 数の 4 分の 1 に当たる。またDallas-Ft. Worth と Houston は, 1978年にはともに New York を第1位の指向地としていたが，1983年には杼 互いが相互に第 1 位の指向地とするパターンに 変化してきたのも特徴的な変化である。

Dallas-Ft. Worth のこの様な中心性の向上 に寄与する要因については, 今後のより詳細な 検討を必要とするが，次の 2 要因はその際に考 慮すべきものとなろう。すなわち，1）近年に 和ける Texas 州を中心とする南部のサンベル 卜地带の経済発展により, 経済諸活動が立地し, 同 hub の中心性が高まったこと，2）緩和後 に大幅に採用された hub and spoke 方式に就 いて，同 hub が一大中心 hub となったこと により，全国的航空ネットワークヘのアクセシ ビリティが急速に高まり，それにともない経済 諸活動が立地し, 周辺部の中心地としての機能 をより一層向上させたこと，の 2 要因である。

New York は依然として最も重要な結節地 域の中心結節点であり，直接支配する hub の 数も48 と不変であるが，その内訳にはこの 5 年
間で若干の変更がみられた。即ち，新たに $6 つ$ の hub が New York を指向するようになっ たのに対し，同数の hub が同市を指向しなく なった。Texas 州では3つの hub が New York を指向しなくなったが，これは既述した Dallas-Ft. Worth の中心性の向上によると考 えてよい。Boston と Albany む New York を指向しなくなったが，これは両 hub が余り に New York に近いためであると考兄られる。 即ち, 規制緩和後, 近距離の航空運賃が上昇し, 人々は近くの都市にはマイカーで移動する傾向 が強くなり，その結果より遠方の hub への航 空流動が主要となったためであると考光られ る。この様な例は他にもみられ, Wisconsin 州 Madison 2 Michigan 州 Grand Rapids が, 最寄りの Chicago から New York を第 1 位 の指向地とするように変化した。

ところで Chicago は, large hub の中でも 主要な hub の一つであるが，この 5 年間に直 接支配する hub の数を13から9へと減少させ た。この原因についてはより詳細な検討を必要 そするが, 前述の人々の近距離移動の際のマイ カ一利用の増加, Chicago 自体の都市発展の 停滞などがとの一因と考兄られる。西海岸に和 いては Los Angeles が依然として最も重要な hub であるが, San Francisco が周辺の hub を従属させて，小さいながら一つの結節地域の 中心結節点となってきた点が注目される。ちな みに，この 5 年間に San Francisco が支配す る hub の数は 3 から 6 へと倍増し, 人口数, 発生集中交通量の伸びとも Los Angeles をか なり上回っている。

以上の考察から, 航空規制緩和は, 1978年か ら1983年の僅か 5 年間に, 航空旅客からみたア メリカの結節地域構造にかなりの変化を及ぼし たと結論できよう。

\section{$\mathbf{V}$ 結 論}


本研究では，1）アメリカに和ける航空規制 緩和前後の航空旅客による結節地域の構造を求 め，航空規制緩和法が結節地域の構造にいかな る変化を与えたか，2）太平洋北西部地域に限 定して, 規制緩和前後の航空旅客の発生集中交 通量の变化率が，地理的要因のみでどれだけ説 明できるか，などについて考察を加えてきた。 その結果次のような結論を得ることができた。

1）航空規制緩和は，一般に大きな hubを 成長させ逆に小さな hub を衰退させた。

2）航空規制緩和は，航空旅客からみたアメ リカの結節地域構造にかなりの变化を及ぼした。 例觉ば，Dallas-Ft. Worth は支配する hub の 数を 5 年間で 6 から 12 と倍増させ, より一層 重要な中心結節点となり, その結節地域をかな り拡大させた。

3）太平洋北西部地域に限って指摘できるこ とであるが，航空旅客の発生集中交通量の規制 緩和前後の変化率は，次の二つの変数によりそ の変動の多くが説明できる。すなわち，a）車
で 3 時間で到達可能なより小さい規模の hub の発生集中交通量の総和と, b ) 最寄りのより 規模の大きい hub への移動時間, の 2 变数で ある。即ち, 発生集中交通量の変化率は, 当該 hub の周辺により規模の小さい hub があれば あるほど，そして最寄りのより規模の大きい hub と時間的に隔たっていればいるほど高く なると指摘できる。

本研究で今後に残された課題は, 結節地域構 造の変化の要因分析を詳細に行うことと, hub の発生集中交通量の変化の要因分析を太平洋北 西部からアメリカ全体に拡大すること，などで ある。

本稿を作成するにあたり, 愛媛大学横山昭市教 授には貴重な御助言を賜った。また，資料収集に ついては Washington 大学 George H. Kakiuchi 教授に，そして資料整理については，愛媛大学学 生, 藤井和弘, 山之内美日両君に大変和世話にな った。ここに厚く和礼申し上げます。な扔本稿の 要旨は, 1987年度日本地理学会春期学術大会にて 発表した。

(愛媛大学法文学部)

\section{The Impact of the Airline Deregulation Act on the Structure of the U.S. Nodal Region}

Setsuo FUJIME

The U.S. Congress passed the Airline Deregulation Act (ADA) in 1978, which put an end to 40 years of air transportation regulation. The author, with special reference to the ADA, tried to make clear: 1) how large an impact the ADA had on the structure of the U.S. nodal regions defined by air transportation passengers, and 2) to what extent the geographical conditions of hubs can explain the variations of the rate of change in the number of air passengers both originating and terminating at hubs before and after the ADA in the Pacific Northwest. The results of this analysis may be summarized as follows:

(1) In general, the ADA has made larger hubs develop and on the contrary, smaller hubs decline by making them compete with each other.

(2) The ADA has effected a considerable amount of change in the structure of the U.S. nodal region. For instance, the Dallas-Ft. Worth hub has become more important for five years (1978-1983) by an increase in the number of hubs, from 6 to 12, which 
are governed by it.

(3) Two factors are identified which have an influence upon the rate of change in the number of air passengers both originating and terminating at hubs before and after the ADA in the Pacific Northwest. They are a) the total number of air passengers at the smaller hubs which can be reached within three hours by car from each of the given hubs, and b) travel time from the latter hub to its nearest larger hub. 